\title{
Investing In the Mekong River Delta of Vietnam - The Opportunity for Small and Medium Enterprises of Korea
}

\author{
Doan Thi My Hanh \\ Associate Professor. PhD in Economics. Faculty of Economics \\ Van Hien University, Viet Nam
}

Ma Bich Tien

Lecturer. Faculty of Commerce and Business Administration

Van Lang University, Viet Nam

Dang Thanh Liem

Lecturer. Faculty of Economics, Van Hien University, Viet Nam

Received: August 2, 2018 Accepted: August 14, 2018 Published: August 31, 2018

doi:10.5296/ber.v8i3.13580 URL: https://doi.org/10.5296/ber.v8i3.13580

\begin{abstract}
This article provides a direction for furfure research in small and medium enterprises invest in foreigner countries; specially in Vietnam market. The major projects that Korea Enterprises invested covered mostly in the Northern of Vietnam provinces such as Bac Ninh, Ha Noi, Hai Phong, Thai Nguyen. Meanwhile, in southern Vietnam, the Mekong River Delta region with many projects calling for investment in agriculture and tourism has not attracted much attention from Korean investors.

The article using the method of descriptive statistics to overview the project investment in agriculture and tourism of the Mekong Delta of Vietnam and points out the advantages of Korean small and medium enterprises (SMEs) in these two sectors. The results of study showed that Mekong River Delta has incentive policies for investment. Besides, with the general policy of Vietnamese government for agriculture and tourism projects, they had incentive policies for foreigner invest in these fields. Moreover, Korea has many small and
\end{abstract}


medium enterprises (SMEs) as well as investing experience in Vietnam. This articles strongly encourages the research of the opportunity for foreigner SMEs invest in tourism and agriculture in other countries, especially emerging market as Vietnam.

Keywords: Investment, Opportunity, Korea, Southwest of Vietnam

\section{Introduction}

Vietnam was the fourth largest destination of investment of Korea. According to reports from General Statistics Office of Vietnam, in 2016, the invested capital of Korea accounted for $30.8 \%$ of total foreign invested capital in Vietnam. Korean enterprises invested mostly on manufacturing, made up $71 \%$ of Korea's total invested capital in Vietnam. Electronics and telecommunications are the two fields that have been invested the most (Oh \& Mah, 2017). From 2014 backwards, Korean investors in Vietnam were large industry corporations, namely Samsung, LG, Kumho, Posco, Lotte, E-Mart,... For the past three years, there have been many small and medium enterprises (SMEs) investors investing independently or representative office of the large corporations. Oh and Mah (2017) found that the reason why Korean SMEs have continuously increased their investment in Vietnam is because of the attractiveness of low-wage and high-quality labor. Although some enterprises did not invest successfully, the proportion was not considerable. In 2014, SMEs accounted for $46.6 \%$ Korea's foreign direct investment (FDI) in the world, particularly in Vietnam the proportion was $60 \%$. Therefore, SMEs played an important role in Korea's FDI in Vietnam.

The majority of Korean SMEs' investment projects have been in Northern provinces of Vietnam, while Southern provinces, especially the Mekong River Delta of Vietnam, have hardly had any project. Meanwhile, this region has quite many projects inviting investment in many fields, including small-scale projects on green agriculture and green tourism suitable for SMEs' ability. This article used descriptive statistics and inferential statistics to systematize the agricultural and tourist projects which the Mekong River Delta of Vietnam has called for investment, in order to provide an overview of the projects inviting investment in these two fields of the region. On this ground, the article analyzed the opportunity of investment for Korean SMEs.

\section{Overview of Korean SMEs}

SMEs play an important role in the economy of Korea. Within 10 years (2005 - 2014), the number of SMEs increased from 2,863,583 firms to 3,542,350 firms. The number of employees in SMEs accounted for $87.8 \%$ of the total employees in all industries. The five fields where SMEs made up the largest proportion were Wholesale and Retail, Accommodation and Restaurants, Manufacturing, Transportation, and Repair \& Other Individual Services (see Table 1). Therefore, it is not surprising that for the past years many SMEs in Wholesale and Retail have invested in Vietnam. The field of Accommodation and Restaurants came second with a proportion of nearly $20 \%$, which shows that this field was also a strength of Korean SMEs. However, the field of Agriculture, Forestry, and Fishery had few SMEs with a very small proportion of only $0.03 \%$, but the average number of employees in each SME was much higher with more than 10 employees while the average number of 
employees was only 4 employees.

Table 1. Five industries Korean SMEs most involved, 2014

\begin{tabular}{|r|l|r|r|r|r|}
\hline & & No. of Firms & Proportion (\%) & No. of Employees & Proportion (\%) \\
\hline & All SMEs & $3,542,350$ & 100.00 & $14,027,636$ & 100.00 \\
\hline 1 & Wholesale \& Retail & 986,370 & 27.85 & $2,833,469$ & 18.40 \\
\hline 2 & Accommodation \& Restaurants & 701,181 & 19.79 & $2,021,946$ & 14.41 \\
\hline 3 & Manufacturing & 392,665 & 11.08 & $3,185,560$ & 22.71 \\
\hline 4 & Transportation & 375,381 & 10.60 & 914,971 & 6.52 \\
\hline \multirow{2}{*}{5} & $\begin{array}{l}\text { Repair \& Other } \\
\text { Individual Service }\end{array}$ & 300,532 & 8.48 & 656,650 & 4.68 \\
\hline
\end{tabular}

Source: Statistics Korea (2014)

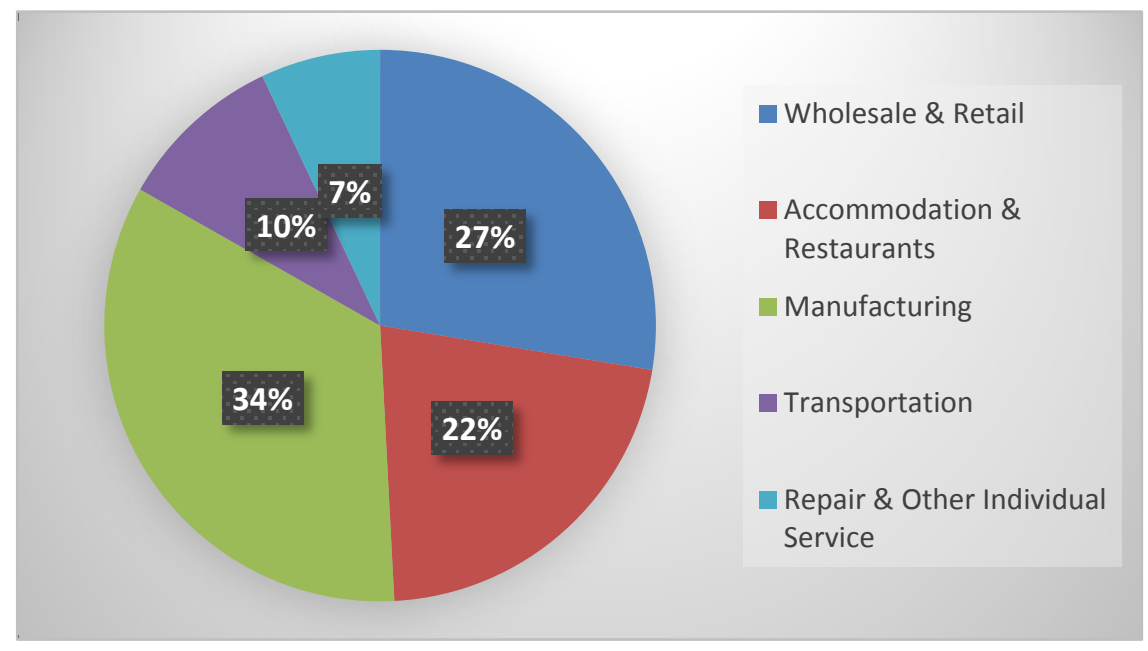

Figure 1. Five industries Korea SMEs invested in Viet Nam

Source: Statistics Korea (2014)

According to the data from statistics of Korea, SMEs invested the most of projected for manufacturing, with $34 \%$ projects because of the attractiveness of the low-wage and high-quality labor. Besides, wholesales \& retails are the second largest of projected that attracted SMEs for investing.

\section{Korean SMEs' investment in Vietnam}

Table 2. Top four countries investing in Vietnam (accumulation of projects having effect as of $31 / 12 / 2016)$

\begin{tabular}{|l|l|l|l|l|}
\hline & Number of projects & Proportion (\%) & $\begin{array}{l}\text { Total registered capital } \\
(\text { Mill. USD) }\end{array}$ & Proportion (\%) \\
\hline Total & 22,594 & & $293,700.40$ & \\
\hline Korea & 5,773 & 25.55 & $50,553.50$ & 17.21 \\
\hline Japan & 3,292 & 14.57 & $42,433.90$ & 14.45 \\
\hline Singapore & 1,796 & 7.95 & $38,255.40$ & 13.03 \\
\hline Taiwan & 2,516 & 11.14 & $31,885.50$ & 10.86 \\
\hline
\end{tabular}




\section{Macrothink}

Source: Vietnam General Statistics Office (2017)

According to the General Statistics Office of Vietnam, in 2016, the number of Korean FDI projects in Vietnam made up nearly $26 \%$ of the total foreign investment projects in Vietnam, and Korean was the country with the most FDI projects. The total registered capital of Korean investors was also the most (more than 50 billion USD), making up $17.21 \%$ of the total registered FDI capital (see Table 2).

Table 2 shows the number of projects and the total registered capital accumulated until 2016. Particularly in 2016, Korea also stood first with 849 projects, making up $32.49 \%$ of the total projects and the total registered capital accounted for nearly $30 \%$ of the total investment capital in Vietnam (see Table 3).

Table 3. Top four countries investing in Vietnam in 2016

\begin{tabular}{|c|c|c|c|c|}
\hline & Number of projects & Proportion \% & $\begin{array}{c}\text { Total registered capital } \\
\text { (Mill. USD) }\end{array}$ & Proportion \% \\
\hline Total & 2,613 & & $26,890.50$ & \\
\hline Korea & 849 & 32.49 & $7,965.20$ & 29.62 \\
\hline Japan & 351 & 13.43 & $3,035.90$ & 11.29 \\
\hline Singapore & 213 & 8.15 & $2,414.70$ & 8.98 \\
\hline Taiwan & 125 & 7.48 & $2,194.40$ & 8.16 \\
\hline
\end{tabular}

Source: Vietnam General Statistics Office (2017)

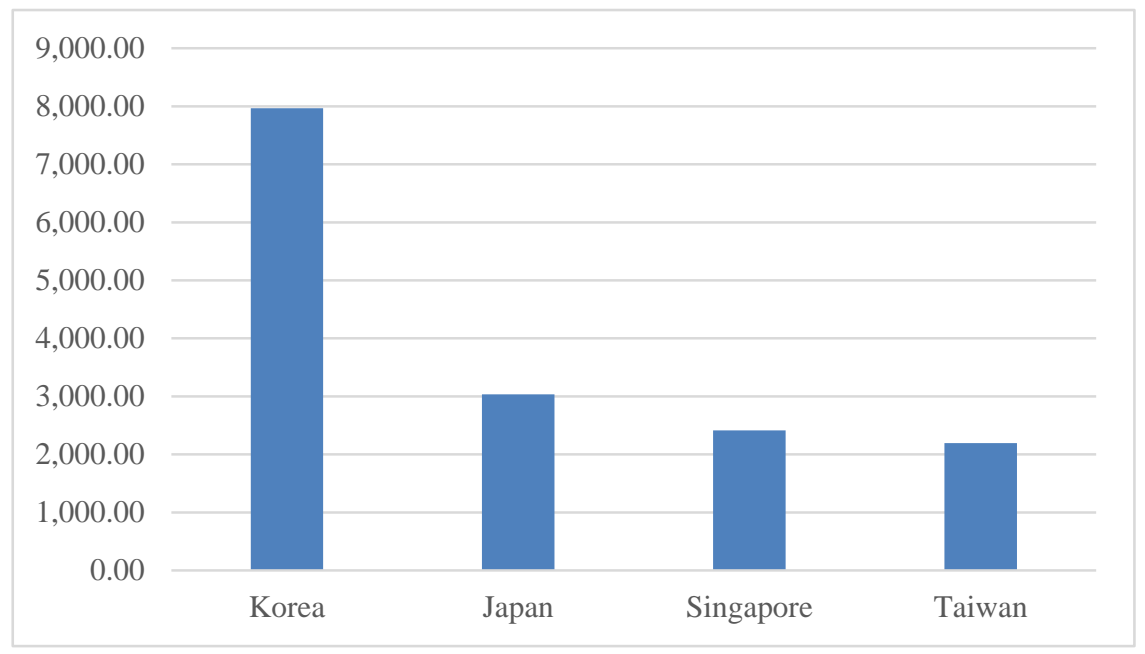

Figure 2. Four countries invested in Viet Nam (source Vietnam General Statistics Office 2017)

Oh (2017) found out the total of number of overseas enterprises, small and medium-sized enterprises (SMEs) accounted for $46.6 \%$ of Korea's FDI in the world, while they took up $60 \%$ in Vietnam as of 2014. Besides, Korea is a country that had the largest of the total registered capital in Viet Nam, with nearly 8,000,000 million USD.

According to Korea Trade-Investment Promotion Agency (KOTRA, 2017), around 95\% of all Korean investment projects were from SMEs with employees less than 500 and sales less 
than 150 million USD. These projects were mostly in the fields of processing and manufacturing industries. Korean large corporations, though accounted for only 5\% of all investment projects, achieved more than $70 \%$ of the total registered capital in Vietnam. The invested areas were mainly provinces in the Northern Vietnam such as Bac Ninh, Ha Noi, Hai Phong, Thai Nguyen (KOTRA, 2017).

Moreover, a survey on 540 Korean enterprises of Korea International Trade Association (KITA) studied in 2015, all enterprises confirmed that they had plans to develop business in the Vietnamese market. The invested fields were mainly processing and manufacturing industries and real estate. Accommodation and catering services accounted for $2.1 \%$ of the total invested capital.

On the other hand, the reasons why Korean SMEs enthusiastically invested in Vietnam is because of the attractiveness of the low-wage and high-quality labor. Oh (2017) pointed out the attractiveness of Vietnam's labor force came not only from its low wage but also from its high quality and education. Wright and Blomenhofer (2017) studied that from 2015 Vietnam had 91.7 million population, with 69.6 million being aged 15 and above. A young, generally well-educated labor force presents significant opportunity for the next phase of Korean manufacturers. With monthly minimum wages ranging between VND 2.4 million and VND 3.5 million (USD 106 - USD 154), Vietnam remains competitive in comparison with other regional FDI destinations such as Thailand (approximately USD 168 per month) and China (approximately USD 240 per month). Vietnam is also a potential consumer market. Besides, Vietnam is one of the most attractive markets in the world with their substantial economic growth and increasing number of middle class. The economy grew $6.81 \%$ with $8 \%$ construction, 7,44\% service increase and 10.9\% of retail sales gain in 2017 (Phuong, 2017). In addition, Vietnam is an attracting market for foreign marketers with over 90 million people and an average annual growth rate of $10-15 \%$ (Tran, 2015). Besides, it is forecasted that the middle class will be tripled in Vietnam between 2012 and 2020 ("Vietnamese Consumers", 2013). With significant growth in middle class, Vietnamese consumers are buying more sophisticated products and services. For example, urban Vietnamese women aged between 20 and 45 have increased their spending on apparel up to $18 \%$ of their monthly income (Breu et al., 2010). Vietnamese consumers show great interests in foreign products as well as travel in foreign countries as their demands get more cultivated (PricewaterhouseCoopers LLP. 2005).

\section{The opportunity for Korean SMEs in the Mekong River Delta of Vietnam}

The figures in Table 4 were taken from the list of the projects calling for investment from the provinces in the Mekong River Delta. There are totally 79 projects in the field of agriculture and 76 projects in the field of tourism (see table 4). The majority of the projects does not suggest the levels of investment capital but leave it to investors' decisions. The agricultural projects may need a lot of labor, so investors may benefit from low-wage and high-quality labor as mentioned above. High quality agricultural products can not only be exported to other markets, but they can also be consumed easily in Vietnam because of the increase of the middle class. Agriculture is also the field of investment which is incentivized: besides the general incentives of the government, the local authorities of the provinces in the region offer 
their own incentive policies, such as remission of land rent fees and remission of water surface rent fees from within 10 years to the whole lifetime of the project, or reduction of 50 $70 \%$ of the total rent fee (Ben Tre People's Committee, 2017).

Table 4. Numbers of agricultural and tourist projects calling for investment in 2017

\begin{tabular}{|l|c|c|}
\hline Province & Agriculture & Tourism \\
\hline Total & 79 & 76 \\
\hline An Giang & 21 & 9 \\
\hline Bac Lieu & 7 & 9 \\
\hline Ben Tre & 8 & 8 \\
\hline Ca Mau & 0 & 2 \\
\hline Can Tho & 1 & 2 \\
\hline Dong Thap & 4 & 11 \\
\hline Hau Giang & 3 & 2 \\
\hline Kien Giang & 10 & 5 \\
\hline Long An & 1 & 2 \\
\hline Soc Trang & 3 & 9 \\
\hline Tien Giang & 1 & 2 \\
\hline Tra Vinh & 18 & 13 \\
\hline Vinh Long & 2 & 2 \\
\hline
\end{tabular}

Source: Extract from the list of projects calling for investment of provinces in the Mekong River Delta of Vietnam (2017)

The tourist projects are rather various, with ecotourism projects being a majority, such as riverside or coastal resorts, entertainment complexes, restaurants, hotels,... Some projects are small scale with an area of around 10 hectares and with no need for large investment capital, which is suitable for SMEs. This is the field in which SMEs have advantage as presented in the previous section of overview of Korean SMEs.

\section{Conclusion}

The Mekong River Delta of Vietnam currently has 60 agricultural projects and 48 tourist projects calling for foreign investment, mainly high-tech agriculture and ecotourism. Among these projects, there are quite many small scale projects with no need for large investment capital, so they are suitable for SMEs' financial ability. In addition, Korean SMEs have advantage in the field of accommodation and restaurants, so they may benefit from investing in small scale ecotourism projects. The opportunity for SMEs when investing in the Mekong River Delta of Vietnam may lie in the market of high quality agricultural products and ecotourism which are developing, because the middle class is increasing with the growth of the economy and incentives in land rent and water surface rent fees.

\section{References}

An Giang People's Committee (2017). The list of the projects calling for investment in 2017, An Giang's Investment Handbook, p.p 33-35 \& 76-77 
Bac Lieu People's Committee (2017). The list of the projects calling for investment in 2017, No $76 / Q Đ-U B N D$

Ben Tre People's Committee (2017). The list of the projects calling for investment in 2017, [Online] Available: http://www.bentre.gov.vn/hoi-nghi-xuc-tien-dau-tu/

Breu, M., Salsberg, B. S., \& Tú, H. T., (2010). Growing up fast: Vietnam discovers the consumer society. Forbes (23 August 2010). [Online] Available:

http://www.forbes.com/2010/08/23/vietnam-retailing-consumerism-leadership-managing-mc kinsey. html.

Ca Mau People's Committee (2017). The list of the projects calling for investment in 2017, No 968/QĐ-UBND

Can Tho People's Committee (2017). The list of the projects calling for investment in 2017, No 1644/UBND-KT

Dong Thap Department of planning and Investment (2017). The list of the projects calling for investment 2015 - 2020, http://skhdt.dongthap.gov.vn/wps/portal/sokhdt/

Hau Giang People's Committee (2017). The list of the projects calling for FDI in 2017. http://www.haugiang.gov.vn/Portal/Default.aspx?pageindex=3\&pageid=6454\&siteid=1

Kien Giang People's Committee (2017). The list of the projects calling for investment in 2017, [Online] Available:

https://www.kiengiang.gov.vn/trang/TinTuc/57/1352/Danh-muc-du-an-keu-goi-dau-tu-tren-di a-ban-tinh.html

Oh, J. H., \& Mah J. S. (2017). The Patterns of Korea's Foreign Direct Investment in Vietnam, Journal of Business and Management, 5, 253-271. https://doi.org/10.4236/ojbm.2017.52023

Phuong, Ha, (2017). Viet Nam economy in 2017 via the number. New Zing. [Online] Available: https://news.zing.vn/kinh-te-viet-nam-2017-qua-nhung-con-so-post807606.html (December 29 2017)

Projects call for invesrment (2016), Long An Investment Promotion Conference 2016, http://en.investinlongan.vn/investment-information/projects-call-for-investment/

PwC, (2015). 2015-16 Outlook for the Retail and Consumer Products Sector in Asia. [Online] Available:

http://www.pwchk.com/webmedia/doc/635593364676310538_rc_outlook_201516.pdf.

Soc Trang People's Committee (2017). The list of the projects calling for investment in 2017, No 2418/QĐ-UBND

Statistics Korea (2014). [Online] Available: http://kostat.go.kr/portal/eng/index.action

Tien Giang People's Committee (2017). The list of the projects calling for investment in 2017, No 331/QĐ-UBND

Tra Vinh Department of planning and Investment (2017). The list of the projects calling for 
Tran, Van, (2015). Vietname Tourism Branding. AP15 Vietnam Conference.

UNCTAD. (2015). World Investment Report. United Nations, New York and Geneva.

Viet Nam General Statistics Office (2017). [Online] Available:

http://www.gso.gov.vn/Default_en.aspx?tabid=491

Vietnamese Consumers are Optimistic, (2013). Warc. [Online] Available: http://www.warc.com/LatestNews/News/Vietnamese_consumers_are_optimisticnews?ID=32 364. (23 December 2013)

Vinh Long People's Committee (2017), The list of the projects calling for investment in 2017, No 940/QĐ-UBND

Wright, J., \& Blomenhofer, M. (2017). The rise of Korean investment in Vietnam How Korean companies can continue to thrive in an exciting but challenging jurisdiction, KROLL Investigations and Disputes.

\section{Copyright Disclaimer}

Copyright for this article is retained by the author(s), with first publication rights granted to the journal.

This is an open-access article distributed under the terms and conditions of the Creative Commons Attribution license (http://creativecommons.org/licenses/by/3.0/). 